\title{
EFEKTIVITAS PEMBERIAN DANA INSENTIF AKREDITASI PROGRAM \\ BETTER EDUCATION THROUGH REFORMED MANAGEMENT AND UNIVERSAL TEACHER UPGRADING (BERMUTU) PADA PRODI PGSD
}

\author{
THE EFFECTIVITY OF ACCREDITATION INCENTIVE FUND ALLOCATION FOR \\ BETTER EDUCATION THROUGH REFORMED MANAGEMENT AND UNIVERSAL \\ TEACHER UPGRADING (BERMUTU) ON PGSD STUDY PROGRAM
}

\author{
Ikhya Ulumudin \\ Pusat Penelitian Kebijakan Pendidikan dan Kebudayaan, Balitbang Kemdikbud \\ e-mail: $\underline{\text { ikhya.puslitjak@gmail.com }}$
}

Naskah diterima: 01/02/2016, direvisi akhir: 30/03/2016, disetujui: 15/04/2016

\begin{abstract}
Abstrak: Tujuan penelitian ini adalah untuk mengetahui pemanfaatan dan dampak pemanfaatan program bantuan DIA BERMUTU. Penelitian ini dilakukan pada 12 perguruan tinggi yang mendapatkan program bantuan DIA BERMUTU dengan metode survey dan teknik pengumpulan datanya adalah wawancara. Hasil penelitiannya adalah program DIA BERMUTU telah dimanfaatkan dan digunakan oleh penerima bantuan untuk peningkatan pengelolaan prodi PGSD. Pemanfaatannya dilakukan melalui program dan kegiatan diantaranya peningkatan kapasitas SDM, peningkatan mutu proses pembelajaran, peningkatan kelengkapan sarana prasarana dan system informasi, dan peningkatan kegiatan penelitian dan pengabdian masyarakat. Dampak dari pemanfaatan tersebut adalah terfasilitasinya prodi PGSD untuk memperoleh akreditasi lebih baik, serta menjadi stimulus prodi PGSD dalam merencanakan pengelolaan yang berkualitas, akuntabel, dan berorientasi pada pencapaian output yang BERMUTU secara berkesinambungan.
\end{abstract}

Kata kunci: Efektivitas, DIA BERMUTU, Prodi PGSD

Abstract: This research was carried out to find out the utilization of DIA BERMUTU Program and the effect of its utilization. The research was conducted in 12 universities, the grantees of DIA BERMUTU program, using survey method and interview as its data collection technique. The result showed that DIA BERMUTU program had been utilized and used by the grantees to improve the PGSD study program management through various programs and activities such as human resource capacity development, learning process quality improvement, enhancement of information system and infrastructure, and development of research and community services. DIA BERMUTU program could facilitate the PGSD Study Program to get a better accreditation level. Beside that, this program can also stimulate PGSD Study Program to have better plan toward more qualified, accountable, and sustainable-qualified-output-oriented management.

Keywords: Effectivity, DIA BERMUTU, PGSD study program 


\section{PENDAHULUAN}

Jenjang pendidikan Sekolah Dasar (SD) merupakan landasan yang sangat berpengaruh pada mutu pendidikan jenjang berikutnya. Untuk itu pemerintah berupaya meningkatkan kualifikasi guru SD sampai dengan jenjang strata 1 (S-1). Dengan berpendidikan S1 diharapkan guru SD lebih mampu memahami perkembangan anak usia SD, dan lebih kompeten dalam melakukan tugas mendidiknya.

Sehubungan dengan hal tersebut, Ditjen Dikti memperluas izin penyelenggaraan program studi S1 PGSD di sejumlah lembaga pendidikan tenaga kependidikan (LPTK). Mengingat prodi S-1 PGSD merupakan prodi yang baru, tidak semua PGSD tersebut memiliki kapasitas untuk memenuhi standar kualitas nasional seperti yang disyaratkan oleh BAN-PT. Dalam rangka meningkatkan kapasitas Program Studi S-1 PGSD, pada awal tahun 2009 Ditjen Dikti berkerjasama dengan World Bank meluncurkan Program Dana Insentif Akreditasi Better Education through Reformed Management and Universal Teacher Upgrading (DIA BERMUTU).

Tujuan utama bantuan DIA BERMUTU adalah untuk mendukung dan memfasilitasi LPTK program studi S1 Pendidikan Guru Sekolah Dasar (PGSD) agar memperoleh akreditasi, dan meningkatkan akreditasi LPTK program studi lainnya. Program DIA BERMUTU digunakan untuk peningkatan kapasitas SDM, peningkatan mutu proses pembelajaran, peningkatan kelengkapan sarana prasarana dan system informasi, dan peningkatan kegiatan penelitian dan pengembangan.

Dalam upaya untuk mengetahui efektivitas pemberian bantuan DIA BERMUTU Program Studi PGSD yang menerima bantuan, dilakukan kajian pemanfaatan dana bantuan DIA BERMUTU dalam pengelolan program studi PGSD, dan dampak pemanfaatannya. Dampak ini dilihat dari perolehan nilai akreditasi serta perencanaan-perencanaan program studi PGSD ke depan setelah dana bantuan DIA BERMUTU selesai.

Rumusan permasalahan dalam penelitian ini adalah belum diketahuinya pemanfaatan dana bantuan DIA BERMUTU dalam pengelolan program studi PGSD dan dampak pemanfaatan program tersebut pada Program Studi PGSD. Tujuan penelitian secara umum adalah untuk mengetahui efektivitas pemberian bantuan DIA BERMUTU pada Program Studi PGSD yang menerima bantuan. Adapun tujuan khusus penelitian ini adalah untuk mengetahui: (i) pemanfaatan dana bantuan DIA BERMUTU dalam pengelolan program studi PGSD, dan (ii) dampak pemanfaatan program DIA BERMUTU khususnya pada program studi PGSD, dilihat dari perolehan nilai akreditasi serta perencanaan-perencanaan Program Studi PGSD ke depan setelah dana bantuan DIA BERMUTU selesai. 


\section{KAJIAN TEORI}

\section{Dana Insentif Akreditasi BERMUTU}

DIA BERMUTU diberikan kepada sejumlah

LPTK dengan tujuan sebagai berikut.

1) Memfasilitasi Program Studi S1 di LPTK PGSD agar memperoleh akreditasi, dan meningkatkan akreditasi program studi LPTK lainnya;

2) Memfasilitasi program studi kependidikan di LPTK untuk menghasilkan guru-guru yang memenuhi tuntutan UU Nomor 14 tahun 2005 tentang Guru dan Dosen

3) Memberikan kemampuan (penguatan) serta motivasi bagi program pendidikan guru dan lulusannya sehingga berdampak pada mutu pendidikan guru di Indonesia.

DIA BERMUTU dikompetisikan untuk program studi PGSD yang memenuhi persyaratan dan memenuhi proses seleksi. Mekanisme perolehan dana bantuan yang diterapkan DIA BERMUTU, adalah adanya usulan kegiatan LPTK yang dilandasi oleh perencanaan pengembangan institusi jangka panjang dengan menyertakan masukan dari pemangku kepentingan, termasuk dari kelompok guru dan perhimpunan masyarakat sipil. Melalui proses ini dapat merefleksikan skala prioritas institusi, regional, dan nasional, serta kesungguhan dan komitmen institusi penerima hibah melalui penyediaan dana pendamping dengan aktivitas spesifik yang menjamin keberlangsungan program dalam jangka panjang (Ditjen Dikti, 2008).

\section{Efektivitas}

Efektivitas suatu program selalu berkaitan antara hasil yang diharapkan dengan hasil yang telah dicapai. Efektifitas dimaknai sebagai tingkat keberhasilan manajemen dalam mencapai tujuan yang telah ditetapkan terlebih dahulu (Komaruddin, 1994). Istilah efektif menunjukkan seberapa baik proses atau ukuran dalam memenuhi pencapaian tujuan organisasi. (Nevizond Chatab, 2007)

Tingkat efektivitas suatu program dapat diukur dengan membandingkan antara tujuan yang telah ditentukan dari hasil nyata yang telah diwujudkan. Jika hasil suatu program yang dilakukan tidak tepat sehingga menyebabkan tujuan atau sasaran yang diharapkan tidak tercapai, dikatakan tidak efektif. Terdapat tiga ukuran efektivitas yakni pencapaian tujuan, integrasi, dan adaptasi. Pencapaian tujuan adalah keseluruhan upaya dalam mencapai tujuan yang dipandang sebagai suatu proses (Streers, M. Richard, 1985).

\section{Akreditasi sebagai indikator mutu pendidikan}

Akreditasi adalah kegiatan penilaian kelayakan program dalam satuan pendidikan berdasarkan kriteria yang telah ditetapkan. Akreditasi pada program studi di perguruan tinggi dilakukan oleh Badan Akreditasi Nasional Perguruan Tinggi (BAN-PT), yaitu badan evaluasi mandiri yang menetapkan kelayakan program studi pada jenjang pendidikan tinggi dengan mengacu pada Standar Nasional Pendidikan 
(PP no.19 th. 2005). Hasil akreditasi merupakan indikator mutu suatu program studi.

Pendidikan yang bermutu khususnya di program studi PGSD menjadi salah satu hal yang utama, mengingat mutu lulusan keguruan akan berimplikasi dengan mutu pembelajaran. Oleh karena itu, agar pendidikan jenjang sekolah dasar dapat bermutu dibutuhkan prodi PGSD yang bermutu pula. Mutu adalah totalitas dari fitur-fitur dan karakteristikkarakteristik yang dimiliki oleh produk yang sanggup untuk memuaskan kebutuhan konsumen (Gasperz, 1997). Untuk mencapai itu, mutu juga merupakan sebuah proses terstruktur untuk memperbaiki keluaran yang dihasilkan (Arcaro, 2007).

\section{Hasil penelitian yang relevan}

Pemberian bantuan dana dalam meningkatkan mutu pendidikan berpengaruh terhadap mutu pendidikan. Hal ini senada dengan hasil penelitian yang berjudul Evaluasi Kebijakan Dana Bantuan Operasional Sekolah Dalam Meningkatkan Mutu Pendidikan: Studi di Sekolah Dasar Negeri Percobaan 1 Kota Malang (Wirawan, 2012). Hasil penelitian ini menunjukkan bahwa Program Bantuan Operasional Sekolah (BOS) meringankan biaya masyarakat dalam menjalankan wajib belajar 9 tahun serta meningkatkan mutu pendidikan. Dalam proses pelaksanaan kebijakan dana BOS dari tingkat kota serta tingkat sekolah di SDN Kota Malang telah berjalan sesuai dengan semestinya dan sesuai dengan prosedur yang tertuang dalam Juknis dana BOS.

Pemberian dana bantuan pendidikan selain dapat meningkatkan mutu pendidikan juga berdampak pada peningkatan status akreditasi. Hal ini sejalan dengan penelitan yang berjudul Pengaruh status akreditasi terhadap minat studi mahasiswa di Universitas Widyatama (Iriani, Oktariana, Lestari, 2007) bahwa minat studi mahasiswa pada teknik informasi dan teknik industri dipengaruhii oleh status akreditasi. Adapun faktor yang paling penting mempengaruhi minat studi mahasiswa adalah faktor kelengkapan sarana dan prasarana di ikuti dengan proses pendidikan dan pembelajaran, layanan administrasi akademik, kompetensi kurikulum, kualifikasi tenaga pengajar, serta kepemimpinan dan anatomi mahasiswa. Faktor kelengkapan sarana dan prasarana mempunyai nilai persentase variansi sebesar 32,386 persen. Hal ini menunjukan bahwa faktor kelengkapan sarana dan prasarana memiliki yang dapat mempengaruhi minat studi mahasiswa di Universitas Widyatama.

\section{Kerangka Berpikir}

Jenjang pendidikan SD merupakan landasan yang sangat berpengaruh pada mutu pendidikan jenjang berikutnya. Untuk itu diupayakan meningkatkan kualifikasi guru SD sampai sampai dengan jenjang S-1. Upaya peningkatan mutu memerlukan biaya yang tinggi, untuk itu Ditjen Dikti berkerjasama 
dengan World Bank meluncurkan program Dana Insentif Akreditasi Better Education through Reformed Management and Universal Teacher Upgrading (DIA BERMUTU) untuk mengembangkan kapasitas dan meningkatkan mutu program studi PGSD S-1 yang dilakukan dengan akreditasi program studi PGSD S-1. Dengan diberikan bantuan tersebut diharapakan dapat berpengaurh terhadap nilai akreditasi serta dapat mendorong perguruan tinggi untuk selalu meningkatkan mutu pendidikan secara berkesinambungan setelah dana bantuan DIA BERMUTU selesai.

\section{METODE PENELITIAN}

Kajian ini menggunakan metode survei. Data pada penelitian ini berasal dari hasil wawancara dengan Kaprodi PGSD penerima bantuan DIA BERMUTU yang dilakukan pada bulan Oktober tahun 2013.

Populasi studi ini adalah seluruh LPTK yang mendapatkan bantuan DIA BERMUTU yaitu sejumlah 49 LPTK. Penentuan sampel dilakukan dengan teknik cluster random sampling berdasarkan kategori A dan B. Kategori A adalah LPTK yang pada tahun 2006 pernah mendapatkan Program Hibah Kompetetif (PHK) sedangkan kategori B adalah LPTK yang pada tahun 2006 belum pernah mendapatkan PHK tersebut. Sampel penelitian ini terdiri dari 12 perguruan tinggi yang meliputi 7 sampel katagori A dan 5 sampel katagori B. Sampel katagori A adalah Universitas Negeri Padang, Universitas Negeri
Semarang, Universitas Negeri Yogyakarta, Universitas Negeri Surabaya, Universitas Negeri Malang, IKIP PGRI Madiun, dan Universitas Lampung. Sedangkan sampel katagori B adalah Universitas Negeri Gorontalo, Universitas Hansanwadi NTB, Universitas Jambi, Universitas Mulawarman, dan Universitas Tadulako.

Dampak pemanfaatan program DIA BERMUTU meliputi jenis-jenis pemanfaatan program dan kegiatan. Jenis-jenis program dan kegiatan tersebut dikelompokkan menjadi peningkatan kapasitas SDM, peningkatan mutu proses pembelajaran, peningkatan kelengkapan sarana prasarana dan sistem informasi, dan peningkatan kegiatan penelitian dan pengembangan. Dampak akhir yang diteliti adalah peningkatan nilai akreditasi.

Pengolahan data yang bersifat kualitatif menggunakan metode deskriptif analitis yang bersifat induktuif, yaitu dengan mengidentifikasi hasil wawancara di masingmasing perguruan tinggi, kemudian mengklasifikasikan dan mengkelompokan, selanjutnya menarik simpulan. Dari hasil wawancara diketahui pemanfaatan dan penggunaan dana bantuan DIA BERMUTU untuk peningkatan pengelolaan Prodi PGSD, serta perencanaan-perencanaan program ke depan setelah dana bantuan DIA BERMUTU selesai.

\section{HASIL DAN PEMBAHASAN}


Pemanfaatan Dana Bantuan DIA BERMUTU

Dana bantuan DIA BERMUTU yang dikucurkan ke 12 Prodi PGSD sampel telah dimanfaatkan baik melalui program, kegiatan ataupun pengadaan sarana prasarana. Penggunaan program bantuan DIA BERMUTU dialokasikan untuk peningkatan mutu Prodi PGSD khususnya untuk mempersiapkan akreditasi Prodi. Secara garis besar, pemanfaatan dana bantuan DIA BERMUTU dikelompokan menjadi empat yaitu: peningkatan kapasitas SDM, peningkatan proses pembelajaran, peningkatan kelengkapan sarana prasaranan dan sistem informasi, serta peningkatan penelitian dan pengabdian masyarakat.

\section{Peningkatan Kapasitas SDM}

Faktor utama yang dianggap memberikan kontribusi terhadap mutu akademik adalah knowledge management (Huysman, 2003). Oleh karena itu, salah satu pemanfaatan bantuan DIA BERMUTU adalah untuk peningkatan kapasitas SDM bagi pendidik dan tenaga kependidikan. Pemanfaatan tersebut antara lain adalah (i) membiayai dosen untuk mengikuti program magang, studi banding, lokakarya, dan pelatihan baik di dalam dan luar negeri; (ii) mengikutsertakan staf administrasi dan pustakawan pada lokakarya, pelatihan IT, pelatihan managerial, pelatihan untuk pembelajaran sistem pelayanan akademik, dan pelatihan administrasi ketatausahaan; serta (iii) membiayai pendidik dan tenaga kependidikan untuk melanjutkan studi ke jenjang yang lebih tinggi.

Kegiatan magang dilakukan dengan mengirimkan dosen dan staf untuk berlatih di perguruan tinggi lain yang sudah terakreditasi lebih baik. Selain itu, terdapat juga studi banding ke PGSD maupun prodi lain, baik di dalam maupun di luar negeri. Kegiatan lokakarya dan pelatihan yang dilakukan didalam kampus dengan mendatangkan tenaga ahli yang berkompeten baik dari dalam maupun dari luar negeri dengan tujuan untuk meningkatkan kemampuan para dosen yang pada akhirnya akan meningkatkan kualitas mereka dalam melaksanakan kegiatan pembelajaran.

Peningkatan SDM tenaga kependidikan seperti pustakawan, administrasi, teknisi, dan tenaga laboran secara umum banyak dilakukan oleh perguruan tinggi melalui program pelatihanpelatihan yang sesuai dengan kompetensi bidang kerja, seperti misalnya dalam peningkatan kemampuan menyusun laporan pertanggungjawaban, pembenahan administrasi, juga penguasaan teknologi informasi.

Dalam kaitannya dengan peningkatan kualifikasi akademik, mayoritas perguruan tinggi sampel juga memberi dukungan dalam bentuk beasiswa studi lanjut ke S-2 dan S-3 bagi para dosen dan staf agar dapat mengembangkan kompetensi keilmuannya. 
Beberapa universitas juga memberi kesempatan pada tenaga administrasi, laboran, dan pustakawan untuk melanjutkan studi ke jenjang yang lebih tinggi untuk meningkatkan kompetensi. Program studi lanjut ini juga diarahkan sesuai dengan bidang kerja yang dimiliki, misalnya pustakawan diarahkan untuk melaksanakan studi lanjut pada program studi perpustakaan. Demikian juga dengan teknisi dan laboran diarahkan untuk mengikuti pendidikan maupun pelatihan yang relevan dengan bidang kerjanya.

\section{Peningkatan Proses Pembelajaran}

Perkembangan ilmu pengetahuan, teknologi, dan seni (IPTEKS) dari waktu ke waktu terus mengalami peningkatan. Perkembangan IPTEKS antara lain berwujud penambahan materi dan kompleksitas materi keilmuan, pembaharuan prosedur dan metodologi dari berbagai bidang ilmu, teknologi dan seni, serta tumbuh pesatnya teknologi informasi dan komunikasi (TIK). Perkembangan IPTEKS ini begitu meluasnya, merambah ke berbagai bidang dan aspek kehidupan, tidak terkecuali pada dunia pendidikan dan keguruan. Dengan demikian peningkatan proses pembelajaran perlu digalakkan baik dari segi kurikulum, proses pembelajaran, maupun dari suasana akademik.

Dana bantuan DIA BERMUTU telah dimanfaatkan untuk pembaharuan kurikulum, perbaikan perangkat pembelajaran, dan peningkatan suasana akademik. Dalam menyusun dan merevisi kurikulum, selain mengikuti perkembangan IPTEKS, perguruan tinggi selalu berpedoman kepada peraturan perundangan yang dikeluarkan oleh pemerintah serta mengacu visi-misi lembaga. Peraturan perundangan tersebut antara lain adalah Undang-Undang Nomor 14 Tahun 2005 tentang Guru dan Dosen, Kepmendiknas Nomor 232/U/2000 tentang Pedoman Penyusunan Kurikulum Pendidikan Tinggi dan Penilaian Hasil Belajar, Kemendiknas Nomor 045/U/2002 tentang Kurikulum Inti Pendidikan Tinggi, SK Dirjen Dikti Nomor 43/DIKTI/Kep/2006 tentang Rambu-Rambu Pelaksanaan Kelompok Mata Kuliah Pengembangan Kepribadian di Perguruan Tinggi, dan SK Dirjen Dikti Nomor 44/DIKTI/ Kep/2006 tentang Rambu-Rambu Pelaksanaan Kelompok Mata Kuliah Berkehidupan Bermasyarakat di Perguruan Tinggi. Untuk mendukung berlangsungnya proses atau transformasi dengan baik, maka perlu perangkat kurikulum yang relevan dengan kebutuhan lapangan, perangkat-perangkat pendukung implementasi kurikulum seperti silabus, RPP, media, dan bahan ajar yang harus terus dikembangkan.

Dalam konteks pembaharuan kurikulum, dana bantuan DIA digunakan untuk pengembangan dan pembaharuan kurikulum PGSD seperti: lokakarya pemuktahiran kurikulum dengan mereviw kurikulum yang dihadiri oleh stakeholder internal maupun eksternal, workshop pengembangan perangkat 
pembelajaran (silabus, bahan ajar dan RPP), seminar, pengembangan media pembelajaran, dan pengembangan kemampuan penelitian.

Untuk mengimbangi perkembangan IPTEKS diperlukan peningkatan proses pembelajaran sehingga lulusan PGSD terpapar dengan perkembangan. Proses kegiatan Pembelajaran di perguruan tinggi dilaksanakan untuk mencapai visi, misi dan tujuan lembaga. Kompetensi lulusan hanya dapat dicapai apabila para mahasiswa dibekali landasan keilmuan dan keterampilan, serta keahlian berkarya secara memadai. Landasan keilmuan dan keterampilan akan berperan dalam meletakan dasar-dasar pengembangan, sementara keahlian berkarya akan mendukung terhadap penguasan kemampuan praktik. Untuk mencapai tujuan pengembangan tersebut maka kegiatan pembelajaran diarahkan pada pengembangan kemampuan belajar mandiri dan kontekstual.

Dalam konteks perbaikan pembelajaran, dana bantuan DIA digunakan untuk melaksanakan kegiatan-kegiatan, seperti: membuat lembaga pengendali atau kontrol mutu pembelajaran, melakukan monitoring dan evaluasi, mengadakan pelatihan bagi tenaga pengajar, mendatangkan tenaga ahli, pengadaan peralatan labolatorium PGSD sebagai penunjang proses pembelajaran. Suasana akademik; terkait suasana akademik mahasiswa PGSD diwajibkan berpakaian rapih dan sopan, peningkatan interaksi antar dosen dan mahasiswa salah satunya kegiatan pengabdian kepada masyarakat, kebijakan bagi dosen untuk selalu siap memberikan konsultasi skripsi bagi mahasiswa.

Ketika memperoleh dana DIA BERMUTU, program-program tersebut dilaksanakan secara lebih baik dan berkualitas karena dukungan pendanaan yang memadai. Program tersebut akan tetap dikembangkan walaupun program DIA telah berakhir. Namun saat mendapatkan bantuan DIA tentunya kegiatan tersebut dapat dilaksanakan secara lebih baik karena dukungan dana yang cukup memadai. Keberlanjutan program-program tersebut adalah keharusan bagi lembaga untuk menyelenggarakannya, karena jika tidak kurikulum akan ketinggalan jaman tidak sesuai dengan perkembangan ilmu pengetahuan, dan bahkan tidak relevan dengan kebutuhan lapangan.

\section{Peningkatan kelengkapan sarana}

\section{prasarana, dan sistem informasi}

Dana bantuan DIA BERMUTU sangat bermanfaat dalam peningkatan pengelolaan pembiayaan, sarana prasarana, dan sistem informasi. Dalam pengelolaan pembiayaan terbukti terjadi peningkatan transparasi penggunaan dana. Transparansi ini dilakukan dengan melibatkan semua unsur termasuk program studi dalam menyusun dan mengusulkan anggaran dan pelaporan. Selain itu ada juga yang menerapkan pembiayaan dengan sistem BLU seperti halnya UNY dan 
Unnes, di mana pembiayaan bersifat mandiri dan melibatkan berbagai unsur unit kerja. Sistem penganggaran yang demikian dapat menjamin akuntabilitas penggunaan anggaran sehingga efektivitas dan efisiensinya dapat terjamin dengan baik.

Dalam peningkatan sarana dan prasarana, dana DIA BERMUTU digunakan untuk pengembangan peralatan laboratorium PGSD, mikro teaching, sarana perpustakaan, prasarana perpustakaan, dan peningkatan sistem informasi. Peralatan laboratorium PGSD sangat penting untuk menunjang proses pembelajaran supaya lebih baik karena ketersediaan sarana laboratorium yang memadai menjadi prioritas utama. Jenis pengadaan sarana laboratorium yang ditingkatkan diantaranya: peralatan musik, $C D$ pembelajaran, LCD, KIT pembelajaran, alat peraga, computer. Selain itu, peningkatan kelengkapan pada peralatan micro teaching.

Perpustakaan merupakan sarana yang penting dalam dunia pendidikan sebagai wahana bagi perkembangan ilmu pengetahuan. Oleh karena itu, juga dilakukan penambahan sarana dan prasarana perpustakaan seperti penyediaan rak buku, koleksi buku dan perluasan bangunan perpustakaan yang dilakukan di beberapa perguruan tinggi sampel. Perpustakaan yang lengkap sangat memudahkan mahasiswa dalam mencari materi pelajaran dan mengerjakan tugas-tugas sebagai wahana pengembangan dan pendalaman ilmu pengetahuan. Sedangkan bagi dosen atau peneliti sangat penting untuk mencari referensi buku yang diperlukan serta memperluas cakrawala pengetahuan yang sesuai dengan bidangnya. Beberapa perguruan tinggi memanfaatkan DIA BERMUTU untuk melengkapi koleksi perpustakaannya dan perluasan perpustakaan.

Peningkatan sistem informasi terlihat dari jaringan internet LAN yang hampir semua perguruan tinggi sampel mengembangkannya. Sistem informasi menggunakan internet digunakan untuk pelayanan administrasi akademik dan kegiatan pembelajaran sehingga pembelajaran dapat berlangsung secara efektif dan efisien. Pemanfaatan sistem informasi yang dilakukan antara lain adalah untuk kegiatan perkuliahan dan pengisian KRS. Pelayanan berbasis TI memberikan kontribusi yang besar bagi efektivitas dan efisiensi penyelenggaraan pendidikan di perguruan tinggi. Hal ini dilakukan oleh Universitas Mulawarman, STKIP Hamzanwadi NTB, dan Universitas Jambi.

\section{Peningkatan Kegiatan Penelitian dan Pengabdian Masyarakat}

Peningkatan kegiatan penelitian dapat dilaksanakan oleh dosen dan mahasiswa bekerjasama dengan pihak lain dengan mematuhi kaidah/norma dan etika akademik sesuai dengan prinsip otonomi keilmuan. Di bidang pengabdian kepada masyarakat, lembaga berusaha memecahkan berbagai 
masalah masyarakat dengan cara menetapkan agenda pengabdian kepada masyarakat (PPM) berbasis pembangunan masyarakat, menyusun berbagai panduan PPM (meliputi usulan, pelaksanaan, dan pelaporan), rekrutmen dosen sebagai dewan pertimbangan PPM, dan mencari sumber dana PPM baik dari sumbersumber internal maupun eksternal.

Kegiatan peningkatan kegiatan penelitian dan pengabdian kepada masyarakat yang telah dilakukan oleh perguruan tinggi melalui pemanfaatan bantuan DIA BERMUTU yang telah dilaksanakan adalah sebagai berikut. Pertama, sebagian besar perguruan tinggi penerima DIA mempergunakan dana tersebut dalam bentuk hibah penelitian bagi dosen. Dalam pelaksanaannya dosen melibatkan mahasiswa, sehingga dalam hal ini tidak saja terjadi peningkatan kualitas dosen, akan tetapi juga berdampak pada peningkatan kualitas mahasiswa. Dana hibah penelitian ini juga ada yang melibatkan guru SD, sehingga sasaran peningkatan menjadi lebih luas pada peningkatan kualitas guru SD yang menjadi mitra penelitian tersebut. Dengan dana hibah penelitian yang diberikan dari DIA BERMUTU, dampak yang paling mudah dilihat dari program hibah penelitian ini adalah adanya peningkatan jumlah dan judul penelitian yang dilakukan oleh dosen.

Bantuan DIA BERMUTU juga dipergunakan perguruan tinggi untuk memacu perkembangan jurnal/karya ilmiah di jurusan dan prodi, selain jurnal ilmiah yang sudah ada di universitas. Jurnal ilmiah ini dapat mewadahi karya-karya ilmiah para dosen yang telah menyelesaikan laporan penelitiannya dalam bentuk artikel ilmiah yang dimuat dalam jurnal. Secara substansi juga sangat cocok berkembangnya jurnal-jurnal di tingkat prodi karena menjadi publikasi bagi karya-karya pemikiran dan penelitian dosen.

Adapun kegiatan pengabdian masyarakat yang telah dilakukan perguruan tinggi penerima bantuan DIA BERMUTU salah satunya adalah dengan mengisi kegiatan di Kelompok Kerja Guru (KKG) dan Kelompok Kerja Kepala Sekolah (KKKS). Kegiatan yang dilakukan antara lain adalah memberikan pelatihan matematika bagi pembelajaran guru-guru SD melalui KKG dan Kepala Sekolah melalui KKS. Selain itu perguruan tinggi juga melaksanakan program dosen ke sekolah yang bertujuan untuk menjadi guru model di sekolah mitra. Dalam kegiatan pengabdian ini, perguruan tinggi juga telah menjalin kerjasama dengan berbagai pihak seperti pemda, perguruan tinggi lain, dan Badan Narkotika Nasional (BNN) dalam bentuk kegiatan yang relevan dengan lembaga mitra.

Berbagai jenis kegiatan yang telah diuraikan di depan, terutama dalam berbagai program peningkatan kegiatan penelitian dan pengabdian diakui telah membawa dampak langsung pada para dosen yaitu pada kenaikan pangkat dosen. Dengan adanya peningkatan kegiatan penelitian dan pengabdian, 
peningkatan kualitas dosen sudah sewajarnya akan diiringi juga dengan peningakatan penghasilan dan kesejahteraan dosen, serta secara tidak langsung akan meningkatkan nilai akreditasi prodi PGSD.

Pemberian bantuan dana dalam meningkatkan mutu pendidikan berpengaruh terhadap mutu pendidikan. Hal ini senada dengan hasil penelitian yang dilakukan oleh Wirawan (2012) yang menunjukkan bahwa bantuan dana ke satua pendidikan, dalam hal ini adalah pemberian BOS ke sekolah ternyata berhasil meningkatkan mutu pendidikan.

\section{Dampak Pemanfaatan Program DIA BERMUTU}

Dampak pemanfaatan program ini diindikasikan oleh dua hal, yaitu peningkatan nilai akreditasi dan stimulus dalam pengelolaan prodi PGSD.

\section{Peningkatan nilai Akreditasi}

Program DIA BERMUTU telah digunakan dan dimanfaatkan dan digunakan untuk peningkatan pengelolaan prodi PGSD yang terlihat pada 12 perguruan tinggi sampel. Sebagai sarana untuk meningkatkan kualitas pengelolaan program studi dana bantuan DIA BERMUTU digunakan dan dimanfaatkan untuk program-program strategis yang meliputi: peningkatan kapisats SDM, peningkatan proses pembelajaran, peningkatan kelengkapan sarana prasaranan dan system informasi, serta peningkatan penelitian dan pengabdian

Program DIA BERMUTU terbukti mampu memfasilitasi prodi PGSD untuk memperoleh akreditasi yang lebih baik. Predikat akreditasi unggul bukanlah tujuan, tetapi bagaimana kenyataan kelembagaan sesungguhnya pantas untuk memperoleh akreditasi unggul. Untuk memperoleh akreditasi unggul, maka tujuh standar akreditasi yang ada harus dioptimalkan keberadaannya. Untuk itu perlu diidentifikasi kebutuhan-kebutuhan utama yang menjadi komponen yang diakreditasi. Oleh karena itu, program DIA adalah salah satu sarana strategis untuk meningkatkan kualitas lembaga baik di tingkat prodi maupun fakultas dan universitas.

Berdasarkan tabel 4.1 terlihat bahwa terjadi peningkatan akreditasi prodi PGSD penerima dana bantuan DIA BERMUTU yang menjadi sampel penelitian. Dari tabel terlihat bahwa Prodi PGSD yang telah mendapatkan bantuan DIA BERMUTU nilai akreditasinya meningkat. 
Tabel 4.1. Akreditasi prodi PGSD penerima bantuan DIA BERMUTU tahun 2009 dan tahun 2013

\begin{tabular}{|l|l|c|c|}
\hline No & \multicolumn{1}{|c|}{ LPTK } & Nilai Akreditasi tahun 2009 & $\begin{array}{c}\text { Nilai Akreditas } \\
\text { i tahun 2013 }\end{array}$ \\
\hline 1. & Univ. Tadulako & Belum terakreditasi & B \\
\hline 2. & IKIP PGRI Madiun & C & C \\
\hline 3. & Univ. Mulawarman & Belum terakreditasi & C \\
\hline 4. & Univ. Lampung & Belum terakreditasi & B terakreditasi \\
\hline 5. & Univ. Negeri Padang & Belum terakreditasi & B \\
\hline 6. & Unesa Surabaya & Belum terakreditasi & B \\
\hline 7. & Univ. Negeri Malang & C & B \\
\hline 8. & Univ. Negeri Semarang & D & B \\
\hline 9. & Univ. Negeri Gorontalo & C & B \\
\hline 10. & STKIP Hamzanwadi Selong & Celum terakreditasi & B \\
\hline 11. & Univ. Negeri Yogyakarta & & \\
\hline 12. & Univ. Jambi & & \\
\hline
\end{tabular}

Dari 12 prodi sampel hanya dua prodi yakni di IKIP PGRI Madiun dan STKIP Hamzanwadi Selong. Nilai akreditasi pada tahun 2009 dan tahun 2013 masih tetap sama dengan nilai C. Hal itu dikarenakan program studi tersebut belum mengajukan penilaian akreditasinya kembali, sehingga nilainya masih tetap sama.

Dengan peningkatan nilai akreditasi, akan berdampak pada peningkatan minat masyarakat untuk mendaftar di program studi PGSD tersebut. Hasil penelitian yang dilakukan oleh Yani Ariani dkk, menunjukan bahwa minat studi mahasiswa pada teknik informasi dan teknik industri dipengaruhii oleh status akreditasi.

DIA BERMUTU sebagai stimulus dalam pengelolaan prodi PGSD selanjutnya

Perguruan tinggi harus merespon program DIA BERMUTU sebagai motivasi dalam menyelenggarakan program pendidikan yang berkualitas. Oleh karena itu, perguruan tinggi harus meneruskan program DIA BERMUTU tersebut melalui biaya internal secara berkelanjutan, sehingga program-program yang dilaksanakan dengan bantuan DIA BERMUTU tidak berhenti ketika program selesai, tetapi terus dilanjutkan sehingga kualitas pelaksanaan pendidikan di perguruan tinggi tetap terjaga.

Dalam kaitannya dengan itu, informasi yang tidak kalah pentingya adalah tentang kesinambungan program yang telah digulirkan oleh pemerintah kepada LPTK khususnya prodi PGSD penerima bantuan DIA BERMUTU. Dari hasil wawancara dapat dikatakan bahwa setiap prodi PGSD di setiap perguruan tinggi siap melanjutkan program peningkatan dan pengembanganya meskipun dana bantuan DIA BERMUTU dihentikan. Hal 
ini dilihat dari terdapatnya perencanaan program dan kegiatan pada program studi PGSD ke depan, walaupun dana bantuan DIA BERMUTU selesai.

Dari 12 sampel penelitian, hanya terdapat dua prodi PGSD yang menjawab belum ada perencanaan kegiatan dan program tahun kedepannya, yaitu perguruan tinggi Unesa dan UNY khususnya kegiatan yang membutuhkan pendanaan yang besar. Ini berarti program DIA BERMUTU menjadi stimulus dalam merencanakan pengelolaan prodi PGSD yang berkualitas, akuntabel, dan berorientasi pada pencapaian output yang BERMUTU dan memiliki relevansi tinggi dengan kebutuhan lapangan bagi sebagian besar penerimanya.

\section{SIMPULAN DAN REKOMENDASI}

\section{Simpulan}

Program DIA BERMUTU terbukti mampu meningkatkan pengelolaan prodi PGSD. Sebagai sarana untuk meningkatkan kualitas pengelolaan program studi PGSD maka dilaksanakan program dan kegiatan strategis yang bertujuan meningkatkan nilai akreditasi. Program dan kegiatan tersebut melalui peningkatan kapasitas SDM, peningkatan mutu proses pembelajaran, peningkatan kelengkapan sarana prasarana dan system informasi, dan peningkatan kegiatan penelitian dan pengembangan. Program-program tersebut meningkat penyelenggaraannya dengan adanya bantuan DIA BERMUTU.
Program DIA BERMUTU dapat memfasilitasi prodi PGSD untuk memperoleh akreditasi lebih baik. Program ini merupakan salah satu sarana strategis untuk meningkatkan kualitas lembaga baik ditingkat program studi, fakultas, maupun individu perguruan tinggi. Selain itu, Program DIA BERMUTU mampu berperan sebagai stimulus dalam merencanakan pengelolaan prodi PGSD yang berkualitas, akuntabel, dan berorientasi pada pencapaian output yang BERMUTU dan memiliki relevansi tinggi dengan kebutuhan lapangan.

\section{Rekomendasi}

1. Perguruan tinggi diharapkan memanfaatkan Program DIA BERMUTU sebagai sarana untuk peningkatan pengelolaan prodi PGSD. Manajemen pengelolaan yang baik akan menghasilkan program-program yang baik dan berkualitas juga. Pengelolaan dan pengembangan standar-standar komponen akreditasi merupakan tolok ukur berkualitasnya suatu lembaga. Lembaga yang BERMUTU adalah lembaga yang memiliki komitmen untuk tetap menjaga kelangsungan penyelenggaraan pendidikan secara berkualitas dan berkelanjutan.

2. Program DIA BERMUTU diharapkan dapat mendampingi perguruan tinggi dalam hal ini Prodi PGSD memperoleh nilai akreditasi minimal B dari Badan Akreditasi Nasional. Meskipun nilai bukan tujuan utama, tetapi berdasarkan nilai 
itulah terpetakan mutu sebuah lembaga atau perguruan tinggi. Program DIA BERMUTU ini pada dasarnya berperan penting dalam meningkatkan mutu suatu lembaga melalui berbagai program baik berupa kegiatan maupun pengadaan. Selain itu, perguruan tinggi harus merespon Program DIA BERMUTU sebagai motivasi dalam menyelenggarakan program pendidikan yang berkualitas. Oleh karena itu, perguruan tinggi harus meneruskan program DIA BERMUTU tersebut melalui biaya internal secara berkelanjutan, sehingga program-program yang dilaksanakan dengan dana DIA BERMUTU tidak berhenti ketika program selesai, tetapi terus dilanjutkan sehingga kualitas pelaksanaan pendidikan di perguruan tinggi tetap terjaga. Dengan demikian perguruan tinggi harus menemukan sumber dana untuk melanjutkan hal-hal yang baik dari program DIA BERMUTU. Tantangannya adalah bahwa perguruan tinggi, fakultas, dan prodi penerima bantuan tidak ditingkatkan kemampuannya dalam mencari sumber dana alternatif. 


\section{DAFTAR PUSTAKA}

Arcaro, Jerome S. 2007. Pendidikan berbasis mutu. Yogyakarta: Pustaka Pelajar

Gasperz, Vincent. 1997. Manajemen Kualitas dalam Industri Jasa. Jakarta: PT. Gramedia Pustaka Utama.

Chatab Nevizond.2007. Profil Budaya Organisasi. Bandung: Alfabeta

Ditjen Dikti. 2008. Mekanisme pengajuan bantuan DIA BERMUTU. Jakarta: Kemdiknas

Huysman, M. and Wit, D. 2003. A critical evaluation of knowledge management practices. Beyond management: MIT Press

Ghozali, dkk. 2013. Strategi pembiayaan dan pendanaan pendidikan di Indonesia. Jakarta: Balitbang-Kemdikbud

Iriani, Yani; Riena Oktariana; dan Sri Lestari. .2007. Pengaruh status akreditasi terhadap minat studi mahasiswa di Universitas Widyatama. Bandung: Universitas Widyatama

Kommaruddin. 1994. Ensiklopedia Manajemen. Bumi Aksara: Jakarta

Steers, M. Richard. 1985. Efektifitas Organisasi. Jakarta: Erlangga.

Sugiyono. 2011. Metode penelitian pendidikan. Bandung: Alfabeta

Republik Indonesia. 2003. Undang-Undang Republik Indonesia Nomor 20 Tahun 2003 tentang Sistem Pendidikan Nasional

Republik Indonesia. 2005. Undang-Undang Republik Indonesia Nomor 14 Tahun 2005 tentang Guru dan Dosen

Republik Indonesia. 2005. Peraturan Pemerintah Republik Indonesia Nomor 19 tahun 2005 tentang Standar Nasional Pendidikan

Wirawan, Muhammad. 2012. Evaluasi Kebijakan Dana Bantuan Operasional Sekolah Dalam Meningkatkan Mutu Pendidikan. Jurnal: Administrasi Publik (JAP), Vol. 13, No. 1, Hal. 12-15 Fakultas Ilmu Administrasi, Universitas Brawijaya, Malang. 